\title{
Sport, Maoism and the Beijing Olympics
}

One Century One Ideology

Dong-Jhy Hwang and Li-Ke Chang

\section{(2) OpenEdition}

\section{Journals}

Electronic version

URL: http://journals.openedition.org/chinaperspectives/3223

DOI: 10.4000/chinaperspectives.3223

ISSN: 1996-4617

\section{Publisher}

Centre d'étude français sur la Chine contemporaine

\section{Printed version}

Date of publication: 1 January 2008

Number of pages: 4-17

ISSN: 2070-3449

Electronic reference

Dong-Jhy Hwang and Li-Ke Chang, "Sport, Maoism and the Beijing Olympics », China Perspectives [Online], 2008/1 | 2008, Online since 01 January 2011, connection on 28 October 2019. URL : http:// journals.openedition.org/chinaperspectives/3223; DOI : 10.4000/chinaperspectives.3223

(C) All rights reserved 
L

\title{
Sport, Maoism and
}

\section{the Beijing Olympics}

\section{One Century, One Ideology}

\author{
DONG-JHY HWANG AND LI-KE CHANG
}

The development of sports in China since the nineteenth century has been influenced to varying degrees by imperialism, nationalism, Maoism, and postcolonial thinking. This paper explores these ideologies from three angles: (i) Mao's early thinking regarding physical culture and sport; (ii) the development of sports under Mao's socialism and the Cultural Revolution; and (iii) China's breakthrough in the post-Mao era. In sum, sport remains connected over time with the idea of "imagined Olympians" and of a response to the "Sick Man complex." The advent of postcolonial thought has opened the possibility of more diverse understandings of sports in China.

$\mathrm{T}$ he slogan of the 2008 Beijing Olympics slogan is "One World, One Dream." Chinese officials claim that this slogan fully reflects the essence and the universal values of the Olympic spirit - unity, friendship, progress, harmony, participation, and dreaming. However, a review of the historical development of sport in modern China shows that sport has more often been connected with political ideology. This article explores the relationship between political ideology and sport in China through a review of Chinese and Western literature.

Nearly a century ago, Tianjin Youth magazine published an article entitled "On Sports Competition." Commenting on the upcoming London Olympics, the author asked, "How long must the Chinese wait to win a medal in the Olympic Games?" He appealed to the Chinese government to take responsibility for developing sports and to host the Olympics in China. ${ }^{(1)}$ On 23 October 1908, educator Zhang Boling (1876-1951) from the Nankai School in Tianjin advocated China's participation in the London games. A slide presentation on the Olympic Games during the opening ceremony of the Sixth United Schools Sports Meet in Tianjin aroused students to ask similar questions: "When will China send an athlete to win in the Olympic Games? When will China send an athlete team to win in the Olympic Games? When will China host the Olympics and invite international delegations to "Peking' for the games?" (2)

These questions must be carefully considered in the context of the historical materials of their time and place. At the same time, it is important to clarify how China's "imagined
Olympians" (3) and "sick man" complex ${ }^{(4)}$ were used and evolved in Chinese and Western literature over the last century, and how China has recognized and presented itself through an image of Western Olympians that is coloured by Western imperialism.

According to Foucauldian methods of discursive analysis, the answer may lie somewhere within the structure of the question. In the same year of 1908, coincidently, a famous sport advocate, $\mathrm{Xu}$ Yibing, who objected to military exercise in schools, used the motto "Strengthen the Chinese national physique, wipe out the shame of 'the sick man of Asia'!" when he took over the first physical education school in China - the Chinese Gymnastic School. ${ }^{(5)}$ In fact, from the nineteenth century to the early twentieth century, a fear of national decline and racial extinction had been planted among Chinese intellectuals, and some began to associate physical education with national strength. One of these concerned intellectuals was Mao Zedong, whose thinking has influenced the development of sport in China for more than a half century.

This paper will discuss the following questions: What was the significance of physical culture and sport in China a cen-

1. Luo Shiming, Zhongguo jindai tiyu bianqian de wenhua jiedu (Interpretation of the transformation of physical culture in modern China), Beijing, Beijing Sport University Press 2007, p. 122.

2. Ibid., p. 122

3. Bale, John, Imagined Olympians, Minneapolis, University of Minnesota, 2002.

4. Fitzgerald, John, Awakening China: politics, culture, and classes in the Nationalist Revolution, San Francisco, Stanford University Press, 1996. 
tury ago? What was Mao's thought on physical culture and sport, and how did it affect the development of sport in China? How has sport developed in the post-Mao era? To answer these questions, this paper is organized into three sections. Section one introduces Mao's early thought on physical culture and sport along with his ideology of nationalism. Section two critically evaluates the development of sports under Mao's socialism and the Cultural Revolution. Section three examines how and why China began to pay attention to international sport and made great strides in the post-Mao era.

\section{Mao's early thought on physical culture}

Mao's early thought on physical culture was affected by the national humiliation of defeat in the Opium Wars and in other subsequent conflicts, which left deep and lasting scars on the entire nation. Sport seemed to play an important role in the process of Western cultural imperialism within various social formations in China. It also played a major role in the transmission of imperial and national ideas from the late nineteenth century onwards. In particular, some constitutional reformers frequently used the human body as a metaphor for a nation or national system. ${ }^{(6)}$ Liang Qichao ${ }^{(7)}$ emphasized physical education as the most important part of education ${ }^{(8)}$ and considered physical culture a crucial factor in developing both the people and the nation. Likewise, Yang Jui-sung has observed that Liang Qichao invested new meaning in the term "sick man of Asia" to stress the importance of national physical reform. ${ }^{(9)}$ The term subsequently appeared frequently in Western and Chinese publications to refer to a weakening or declining nation such as old Turkey or the Manchu Empire in the late nineteenth century. It is Liang who first applied the term for a nation to actual Chinese people in his article entitled "New Citizen" (1903), where he wrote, "It's tragic that none of our four hundred million people have a sound physique. A nation composed entirely of sick individuals is surely a sick nation. ${ }^{(10)}$

Perhaps inspired by Liang, the author Zeng $\mathrm{Pu}$ subsequently used "Sick Man of Asia" (Dong ya bing fu) as a pseudonym to publish a very popular novel, Flower in an Ocean of Sin (Nie hai hua), which helped disseminate the term rapidly throughout China. Following Liang, public opinion appropriated "sick man" to refer to the humiliating weakness of Chinese people, and the term became popular among Chinese writers. Ironically, however, as time went on, the Chinese came to regard the phrase as a contemptuous criticism from the West, gradually forgetting that it had been invented and imposed by Chinese. With this transferred attribution came a determination to "wipe out" the humiliation of the "sick man of Asia" through triumph in international sporting competitions. ${ }^{(I I)}$

Modern Chinese nationalism manifested itself on 4 May 1919, when more than 3,000 Beijing students endorsed a manifesto denouncing the decision of the Paris Peace Conference to transfer Germany's concessions in Shandong Province to Japan. The student demonstration against Japanese imperialism provoked similar demonstrations in other major cities, not only by students but also by the merchant class and patriots of various stripes. The May Fourth Movement was a milestone in the growth of Chinese nationalism, and interest in the West and its concepts of democracy, science, and modernization were further challenged by Marxism as the impact of the October Revolution of 1917 in Russia made itself felt. It was during this debate that the major political divisions between the Nationalists and Communists arose.

As a faithful reader of New Youth, a magazine established in 1915 by the founder of the Chinese Communist Party, Chen Duxiu, Mao was deeply inspired by the New Culture Movement and was influenced by Chen's observations on physical strength in an earlier article. Mao's first article, "A Study of Physical Culture," published in New Youth in April 1917, can be regarded as one of the most influential writings on sport in China. Mao's arguments obviously followed Chen's earlier article promoting man's bestial nature (shouxing zhuyi). At a time when nationalism was spreading throughout China, both Mao and Chen believed that Chinese people were suffering the catastrophe of losing their country. Mao argued:

5. Gao Cui, Cong dongya bingfu dao tiyu qiangguo (From sick man of Asia to sports superpower), Chengdu, Sichuan renmin chubanshe, 2003, p. 9. Hsu,Yuan-min, The Diffusion of Physical Education Thought of Intellectuals in Modern China, Taipei, National Taiwan Normal University Press, 1999, pp. 99-121.

6. Susan Brownell, Training the Body for China: Sport in the moral order of the People's Republic, Chicago, Chicago University, 1995, p. 45.

7. Mao's first strictly political ideas were inspired by Liang Qichao.

8. Gu Shiquan, Zhongguo tiyushi (Chinese History of Sports), Beijing, Beijing Sport University Press, 1997, p. 187.

9. Yang, Jui-sung, "Imaging National Humiliation: 'Sick Man of East Asia' in Modern Chinese Intellectual and Cultural History," Journal of History of National Chengch University, 23, 2005, pp. 1-44.

10. Ibid., p. 21

11. Gao Cui, Cong dongya bingfu dao tiyu qiangguo op. cit., p. 9; Hsu Yuan-min, The Diffusion of Physical Education Thought of Intellectuals in Modern China, op. cit., pp. 99121. 
Our country is being drained of its strength. Public interest in martial arts is flagging. The people's health is declining with each passing day. These phenomena deserve serious concern. Exponents of physical education have over the years failed to accomplish anything because they have never gotten to the root of the problem. Our country will weaken further if things are allowed to continue unchanged for long. It should be noted that athletic feats such as marksmanship and shot-putting are external skills that result from training, whereas muscular strength is something internal that enhances performance. How can a person shoot accurately or make a long-distance throw if he has a poor physique and is afraid of weapons? Muscular strength comes from training, which must be done conscientiously. Physical educators of today have devised a few methods, but they have failed to achieve the desired results. This is because external forces have little appeal to a public that is unaware of the real significance of physical education. What are its effects and how should one go about it? Since people are all at sea with these questions, it is only natural that little result has been attained. To make physical culture effective, it is imperative to activate the minds of the people and make them sports-conscious. $^{(12)}$

Mao, like Chen Duxiu, emphasised the fitness and hygiene aspects rather than the Western competitive aspect of sports throughout his life. His early article also expressed the nationalism and admiration for the militaristic spirit that he retained throughout his career. Mao's advocacy of physical culture and exercise was aimed at saving the country, but Chen Duxiu disagreed with the combination of physical education and military drills embodied in the CCP's sport programme under Mao's leadership while the party struggled for survival from 1927 to 1949.

From the nineteenth century to the early twentieth century, a strong current of nationalism influenced physical culture in China. The Chinese Communists were ardent nationalist long before 1937, and they played a crucial role in transforming the primitive xenophobia of the peasantry against the Japanese invaders into a modern nationalist response. ${ }^{(13)}$ This strong nationalist sentiment became one of the key features of Mao's political thought. Like the nationalism of intellectuals that clashed with their rejection of China's cultural heritage, Mao's nationalist beliefs were not easily reconciled with the internationalist content of Marxism. This ideological conflict would give rise to many tensions embodied in the development of physical culture and sport after the establishment of the New China.

\section{Sport, Maoism and the Cultural Revolution}

The CCP divided the future development of Chinese society into two successive phases, namely the bourgeois-democratic revolution and the socialist revolution. The New Democracy was the term used to describe the first of these phases. Its policies and orientation emanated from an essay by Mao Zedong published in 1940. "On New Democracy" outlined the principles of a transitional system in which a temporary alliance of workers, peasants, petty bourgeoisie, and national bourgeoisie would co-exist under CCP leadership. The period of New Democracy would effectively come to an end with the socialist transformation of industry and the drive for collectivisation in 1953. When Mao commented upon the New Democracy, he explained precisely why China needed to build a new society, state, and nation. ${ }^{(14)}$

Sport was seen as an important part of China's new national culture, but Mao is reported to have made few significant statements on the nature of physical culture. In 1952, at the June inaugural meeting of the All-China Sports Federation, he called on the Chinese people to "Develop physical culture and sport, and strengthen the physique of the people." (15) In 1953, during a speech on behalf of the Presidium of the Second National Congress of the New Democratic Youth League of China, Mao said:

Now we must make sure that everybody, including workers, peasants, soldiers, students and cadres, can keep fit. Of course, it does not necessarily mean that if you are in good health you will be good at study, for study must be done in the proper way... Now it is necessary to arrange some recreation for which there

12. Chen Duxiu, "Jin ri zhi jiao yu fang zhen (Present educational policy)," New Youth Volume 1, no. 2, 1915, pp. 1-4.

13. Mao Zedong, A Study of Physical Culture, Beijing, People's Sport Publishing House Press, 1996, pp. 3-4.

14. Maurice Meisner, Mao's China and After: A History of The People's Republic, Free Press, 1999, p. 39

15. "For many years we Communists have struggled for a cultural revolution as well as for a political and economic revolution, and our aim is to build a new society and a new state for the Chinese nation. The new society and new state will have not only a new politics and a new economy but also a new culture." Selected Works of Mao Zedong Volume II, Oxford, Pergamon Press, 1967, pp. 339-384. 


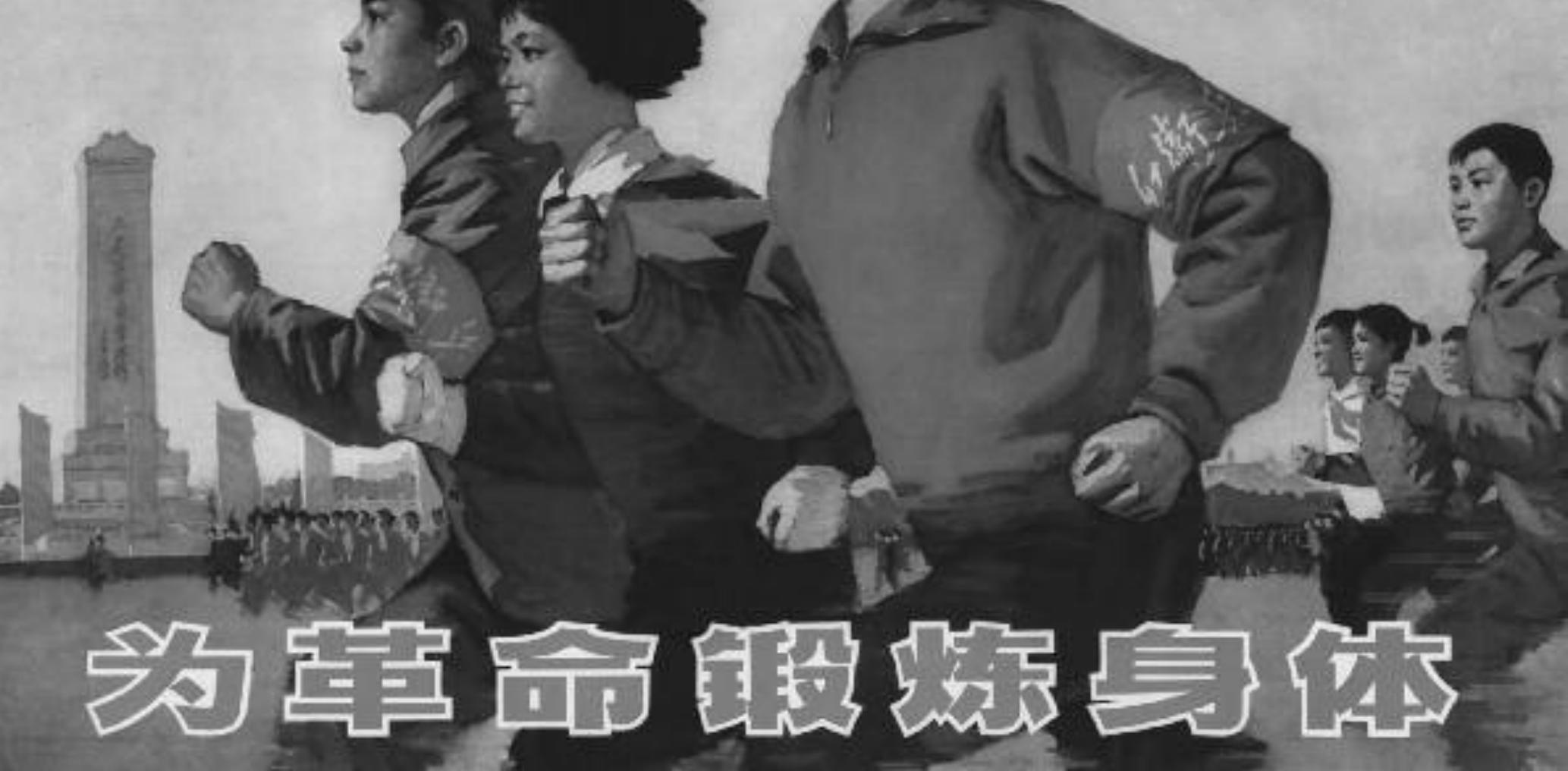

must be time and facilities, and this end should be firmly grasped too. The Party Central Committee has decided to cut down the number of meetings and study hours, and you must see to it that this decision is carried out. Challenge anyone who refuses to do so. In short, young people should be enabled to keep fit, study well and work well. ${ }^{(1)}$

In this statement Mao illustrated his earlier views regarding young people, in particular those who needed more time for play, recreation, and sport. Mao saw in them the hope of building a new China. He used the slogan "Keep fit. Study well. Work well." (17) Mao's later statement came in a speech on 27 February 1957, "On the Correct Handling of Contradictions Among the People," when he said, "We should enable everyone who receives an education to develop morally, intellectually and physically and became a worker possessed of both socialist consciousness and a general education." ${ }^{(18)}$ Although these statements are simple, their significance lies in their constant citation, and in the fact that they, combined with Mao's 1917 essay, comprise the substance of Chinese communist physical culture policy during the Mao era. Al-
The slogan of the poster explains that it is necessary " to exercise one's body for the revolution." () IISH Collection of Stefan R. Landsberger http://www.iisg.nl/ landsberger/ though Mao did not mention sport in "On New Democracy," he summarised the direction the new democratic culture should take:

New democratic culture is national... New democratic culture is scientific... New democratic culture belongs to the broad masses and is therefore democratic... A national, scientific and mass culture-such is the anti-imperialist and anti-feudal culture of the people, the culture of New Democracy, the new culture of the Chinese nation. ${ }^{(19)}$

In line with Mao's philosophy, Feng Wenbin, the inaugural president of the All-China Sports Federation, spelled out the task of physical culture at the 1949 meeting of the federation, where he stated that the motto of the New Democratic physical culture was "to develop sports for people's

16. See Mao's words in New Physical Culture, 25 July 1952, p. 2.

17. In Selected Works of Mao Zedong, Volume V, Oxford, Pergamon Press, 1977, pp. 96-97.

18. Ibid., p. 97.

19. Ibid., p. 405 
health, New Democratic construction, and the people's national defence." ${ }^{20)}$ In short, Feng defined the New Democratic physical culture as national, scientific, and mass. In terms of national physical culture, Mao argued that Chinese sport was national and that "it opposes imperialist oppression and upholds the dignity and independence of the Chinese nation. It belongs to our own nation and bears our own national characteristics." (21)

Chinese sport needed a national character, but it also needed to combine with other advanced sport systems such as the successful sports development model of the Soviet Union at that time. Chinese sport was to be a part of the world's "New Sport." In terms of scientific physical culture, Chinese sport was opposed to all feudal and superstitious ideas, and stood for seeking truth from facts, for objective truth, and for the unity of theory and practice. ${ }^{(22)}$

Viewed as unified and progressive, sport had to contribute to Communist political action, which formed a systematic united front against imperialism and feudalism. Furthermore, both the body and the mind had to be kept in balance in terms of overall human development. In terms of mass physical culture, sport was viewed as serving and belonging to the masses. From the schools to the factories, from the cities to the villages, and from the intellectuals to labourers, sport had to be viewed as spreading throughout the masses. ${ }^{(23)}$

In Feng's description, the New Democratic physical culture was one of the core themes of Mao's New Democracy. ${ }^{(24)}$ The vision of a national physical culture was shaped by Mao's thoughts on Chinese nationalism. The argument about scientific physical culture did not require sport to conform to the principles of science or for all sports programmes to adhere to the principles of physiology, hygiene, anatomy, and physics, but rather required a close relationship between physical culture and scientific research. It accommodated Mao's thoughts on anti-feudalism rather than on scientific method. Accordingly, a national, scientific, and mass physical culture was based upon the anti-imperialist and anti-feudal culture of the people, the culture of New Democracy, and the new culture of the Chinese nation. In other words, New Democratic physical culture meant new physical culture, while old physical culture referred to sports development before 1949.

Following Feng's explanation of New Democratic physical culture, $\mathrm{Xu}$ Yingchao in 1950 provided a critique of the essential characteristics of "old" physical culture: ${ }^{(25)}$

Modern Chinese sport methods, organisations and theories have been copied from the USA, which is a capitalist imperialist state, its politics, economics, military and education all serve the bourgeoisie. The American imperialists spread their sport not because they were concerned about the health of the Chinese people, but because sport was an ideal tool of cultural imperialism. The American imperialists emphasised to the Chinese people that American sports equipment is the best, their athletes are the fastest and their basketball team is the top one... in the world. American sport was perfect in every field. The Chinese Old physical educators always believed that American sport was superior to China's. American sport served the dominant classes and was not for masses. ${ }^{(26)}$

Regarding Xu's statements on "old" Chinese sport, it must be noted that sport was not only copied from the United States, but that its advocates also disseminated the superior image of American sport and endowed American sport methods, organisations, theories, and equipment with cultural imperialism. Certainly, as has been indicated here, new physical culture accompanied Mao's anti-imperialist thoughts on Chinese nationalism. This is one of the reasons why New China developed a "new" physical culture. On the other hand, apart from Western sport, the New Democratic physical culture could be seen as empty theory from Mao's thoughts, which did not develop into a sports policy or system in the New China. In fact, China learned sport from the Soviet "Labour-Defence System" during 1950 and 1957.

China copied a great deal from the Soviet sports system in the early years of the People's Republic. The editor's first column in New Physical Culture, for example, declares that "To establish New Physical Culture, we must learn from the Soviet Union and other People's Democracies." (27) In a speech at a preparatory meeting of the National Physical Culture Committee in 1950, Vice Chairman Zhu De insisted, "We shall learn well from the sports experience of the Soviet Union." ${ }^{28)}$ A few months later, while the first Soviet

20. See M. Meisner, op. cit., pp. 380-382.

21. In New Physical Culture, 1 July 1950, pp. 8-9.

22. See M. Meisner, op. cit., p. 380.

23. Ibid., p. 381.

24. See M. Meisner, op. cit.

25. See M. Meisner, op. cit.

26. In New Physical Culture, 1 July 1950, pp. 10-11.

27. Ibid., p. 10

28. Ibid., p. 6 
ment Commission on Physical Culture held in Beijing on 16-22 January 1954. During this meeting, Vice-Chairman Zhu De clarified the connection between national defence and physical culture, arguing that "In the field of national defence, powerful and skilful bodies are needed by the country. Because of this, young people must be strong in physique and bright and lively, courageous and sharp, tough and unyielding." (32) The Labour Defence System (called "Ready for Labour and Defence" in the Soviet Union) was an essential part of the Soviet influence on Chinese sport and physical education in schools.

Sport and physical education policy also reflected important aspects of Mao's thinking on physical culture and sport. Physical education became a compulsory subject in schools during the early 1950s. Ma Xulun, the Minister of Education, reported the policy and task of educational work in 1951:

The adoption of effective steps for carrying out Chairman Mao's principle of "Health above all" to improve the students' state of health, and, on the prevailing foundation, to improve the remuneration of middle school and elementary schools teachers... The Physical Culture Committee should be established to guide all schools in faithfully carrying out the policy of "Health above all," in reducing the students' amount of class work and after class activities, to promote sports activities and recreation activities. ${ }^{(33)}$

Mao's principle of "health above all" developed into China's early policy of physical education in schools. In his speech "On the Correct Handing of Contradictions Among the People," Mao announced that "our educational policy must enable everyone who receives an education to develop morally, intellectually and physically and become a worker with both socialist consciousness and culture." ${ }^{(34)}$ Physical education became a significant part of socialist education in schools. Each of China's two constitutional documents made reference to physical culture. The Common Programmethe legal guidelines before the adopting of a Constitution in 1954-refers both directly and indirectly to physical culture. Article 41 states: "Culture and education in the People's Republic of China are New Democratic, that is, national, scientific, and popular. The main reasons for raising the cultural level of the people are: training of personnel for national construction work; liquidation of feudal, comprador, fascist ideologies; and development of the ideology of serving the people." ${ }^{(35)}$ Physical culture was also mentioned in Article 48: "National sports shall be promoted. Public health and medical work shall be extended and attention shall be paid to safeguarding the health of mothers, infants and children." ${ }^{(36)}$ In short, the aims of New China's physical education were seen as part of the entire New Democratic culture and education system, which was viewed as national, scientific, and popular.

New China naturally relied on the Soviet model to achieve the goals of new physical culture. A study of Soviet experience in physical education began in the early 1950s. The Soviet guidelines for physical education for grades 1-4, 5-7, and 8-10 were translated into Chinese as a PE teacher's guide. Soviet manuals on physical education were studied to aid China in setting up its own PE system. This included the aims and responsibilities of $\mathrm{PE}$, the different physiological traits of various age groups, basic methods and problems of $\mathrm{PE}$, school testing and planning of $\mathrm{PE}$, the nature of female $\mathrm{PE}$ and the organisation of school PE. Through this study of Soviet experience, Chinese educators concluded that physical education should be considered a subject on a par with all others.

The Labour Defence System was largely confined to schools above middle school level in the first half of the 1950s. ${ }^{(37)}$ Given the Labour Defence System's similarity to the Soviet "Ready for Labour and Defence" system, ${ }^{(38)}$ five basic aspects of Chinese physical education were recognised at this stage: (i) Exercise was the core of the physical training programme. Participation in a varied set of exercises was viewed as preparation for all other aspects of physical education; (ii) Physical education involving both games and dance were included in the middle school programme; (iii) Sports were seen as an extension of basic exercises with competition; (iv) The Labour Defence System - physical education involved training for labour and defence - was the main focus of the upper school physical education programme, and always had a military flavour; (v) Physical education involved complete patriotic and socialist education. Mao's influence on the new physical culture may have been reflected in China's Constitution in 1954. In referring to the early achievement of the CCP - for example, in the

32. Ibid., p. 3.

33. South China Morning Post, No. 748, 9 Feb 1954: 14

34. Ma Hsu-lun [Ma Xulun], "Minister of Education Ma Hsu-lun Reports on Education Accomplishments During the Past Year," in Survey of Mainland Press (142) 25 July 1951, pp. 5-12.

35. See Selected Works of Mao Zedong, vol. 5, op. cit., p. 405.

36. Current Background, (9) 21 September 1950, p. 11.

37. Ibid., p. 12.

38. New Physical Culture, 30 July 1951: 18-20; Sport History, September 1989, pp. 76-77. 
preparatory meeting for the Eighth National Congress in 1956 - Mao said:

China used to be stigmatised as a "decrepit empire", "the sick man of East Asia", a country with a backward economy and a backward culture, with no hygiene, poor at ball games and swimming, where the women had bound feet, the men wore pigtails and eunuchs could still be found, and where the moon did not shine as brightly as in foreign lands. In short, there was much that was bad in China. But after six years' work of transformation we have changed the face of China. No one can deny our achievements. ${ }^{(39)}$

Obviously, Mao's thoughts on physical culture were coloured by his views on nationalism from 1917 to 1956 . After that, Mao increasingly questioned the validity of the Soviet model as a guide to Chinese development. In a speech entitled "On the Ten Great Relationships," Mao emphasized the importance of light industry and agriculture, industrialization of the countryside, decentralized planning, labour-intensive projects, the development of inland areas, and the use of moral incentives rather than material ones in stimulating revolutionary commitment. ${ }^{(40)}$ This collection of strategies, in Mao's view, would lead to rapid economic development and allow China to overtake the capitalist West. The Great Leap Forward campaign was launched in 1958 to realize this aim, but it also reflected Mao's utopian vision of creating a specifically Chinese form of socialism, which entailed a renewed emphasis on the key role of the peasantry and the ultimate achievement of a "collectivist cornucopia." ${ }^{(4)}$ This resulted in a considerable setback for sport and physical education and the Labour Defence System during the Great Leap Forward.

Although Chinese sport was curtailed, a nation-wide sports system managed to be established during this period. Large banners emblazoned with three Chinese characters proclaiming the Great Leap Forward - "Da Yue Jin" - expressed a reversal of economic policy that called for a dramatic rise in industrial production. Mao's introduction of the slogan "more, faster, better, more economical" (duo kuai hao sheng) at a conference in Chengdu in 1958 resulted in widespread implementation of "more and faster" at the expense of "better and more economical," and the failure of the Great Leap Forward can ultimately be attributed to politics rather than economics. ${ }^{(42)}$

The Great Leap Forward destroyed China's system of statistics, which in turn affected the "Ten-year Guidelines for
Sports Development" that called for " 40 million people to achieve the standard of the Labour Defence System, 8 million people to achieve the basic sports standard, and 5,000 people to become top athletes." ${ }^{(43)}$ The guidelines further aimed at a general achievement of the basic standard of labour defence, with the first target set at 150 million and the second at 200 million. The first general target set for active sports participants was set at 50 million and the second at 70 million, while the first target for top-notch athletes was 10,000 and the second 15,000. ${ }^{(4)}$ These high targets for sports development were almost impossible to achieve because of the tendency toward untruthfulness, exaggeration, and formalism. ${ }^{(4)}$ This tendency finally ceased in 1960, when the CCP and Mao admitted the errors of the Great Leap Forward and launched a new policy of recovery and readjustment.

Following on the heels of the Great Leap Forward, the development of sports in the early stage of the Cultural Revolution was affected by disruption of competitive sports, the dismantling of the training system, the closure of sports schools, the discontinued participation of Chinese teams in overseas competitions, and the condemnation and persecution of outstanding athletes as offspring of the bourgeoisie. ${ }^{(46)}$ Evidence of the damage inflicted on Chinese sports from 1968 to 1970 can still be found, particularly in the form of dazibao (big character posters) used to attack individual CCP members during the Cultural Revolution. Mao Zedong's 1966 dazibao entitled "Bombard Headquarters" ${ }^{(47)}$ was interpreted as an attack on Liu Shaoqi, Deng Xiaoping, and other prominent leaders of the Party apparatus, and the Maoist position became increasingly radical during the early stage of the Cultural Revolution as the struggle among the top leadership intensified.

In a Red Guard dazibao, He Long, the CCP's first Sports Minister, was attacked for supporting the revisionist sports policy and publications of Liu Shaoqi and Deng Xiaoping,

39. James Riordan, Sport in Soviet Society: Development of Sport and Physical Education in Russia and the USSR, Cambridge, Cambridge University, 1977, pp. 410-415.

40. See Selected Works of Mao Zedong, vol. 5, op. cit., p. 313.

41. Ibid., pp. 284-307.

42. Roderick MacFarquhar, China Under Mao: Politics Takes Command, Massachusetts, The Massachusetts Institute of Technology, 1972, p. 467.

43. Ibid., pp. 309-310.

44. "Report about the Ten Year Guidelines for Sports Development" in Archive of the State General Sports Administration of China, 8 September 1958.

45. Ibid.

46. See Gu Shiquan, op. cit., p. 350.

47. Fan Hong, "Two Roads to China: The Inadequate and the Adequate," in The International Journal of the History of Sport, 18 (2), 2001, p.158. 
and most of his colleagues were also attacked as revisionists and counter-revolutionaries. ${ }^{(48)}$ Deputy sports ministers Rong Gaotang, Li Menghua, and $\mathrm{Li} \mathrm{Da}$, as well as Wang Ling in the State Physical Culture and Sports Commission, were brought down. ${ }^{(49)}$ Sports development was discontinued, mass sport was eliminated, sports training programmes were replaced by political struggle sessions, and New Physical Culture and Physical Culture News ceased publication. The National Sports System was vilified as an independent realm beyond proletarian politics and CCP control. In a dazibao entitled "My Accusation," Zhuang Zedong, who won the 26 $6^{\text {th }}$ World Table Tennis Championship in Beijing in 1961, accused He Long and Rong Gaotang of revisionist policy and stated that (i) he was physically abused for over eight years in the table tennis team, (ii) he became a seed of revisionism under Rong Gaotang's guidance, and (iii) he wanted to revolt, he wanted to rebel, and he wanted to be a servant of the people. ${ }^{(50)}$ These dazibaos typically ended with the slogan "Bring down Liu Shaoqi, Deng Xiaoping, He Long, and Rong Gaotang! Long Live Mao Zedong Thought! Long Live Chairman Mao!" ${ }^{(5)}$ He Long was tortured both mentally and physically and finally died on 9 June 1969. ${ }^{(52)}$

Further tragedies included the suicides of three top table tennis players during the "Cleanse the Class Ranks" campaign, which was modelled on pilot studies at six factories and two universities in Beijing that were under Mao's personal supervision. ${ }^{(3)} \mathrm{Fu}$ Qifang, a famous table tennis coach and player, came from Hong Kong with Jiang Yongning to join the Chinese National Table Tennis Team in 1952. Fu Qifang was accused of being a spy and tortured by other athletes in denunciation meetings, ultimately hanging himself on 16 April 1968. Jiang Yongning, accused of being a Japanese spy, hanged himself on 16 May 1968. A third table tennis player from Hong Kong, Rong Guotuan, who had won the first world table tennis championship in Chinese sports history in 1959, hanged himself on 20 June 1968. In his last letter, Rong wrote, "I am not a spy. Please do not suspect me. I apologise to you all. I value my honour more than my life." ${ }^{(54)}$ These were the most notorious tragedies in Chinese sport during the Cultural Revolution. The Chinese sports management, training, and competition system was completely abolished in 1967, and most sports teams were dismantled, including 47 provincial and municipal football teams comprised of 1,124 players and 115 professional coaches. Most sports training equipment and facilities were destroyed, and stadiums became gathering places for denunciation meetings. ${ }^{(5)}$ Jung Chang comments that the People's Sports Stadium no longer hosted any kind of sport, since competitive games were condemned by Mao and athletes had to devote themselves to the Cultural Revolution. ${ }^{(56)}$ Sports were replaced by activities expressing loyalty to Chairman Mao, such as "loyalty dances," which were physical exercises following the rhythms of Mao's quotations. ${ }^{(57)}$ As Chang testifies:

\section{In the autumn of 1968 a new type of team took over my school; they were called "Mao Zedong Thought Propaganda Teams"... The old textbooks had all been condemned as "bourgeois poison", and nobody was brave enough to write new ones. So we just sat in classes reciting Mao's articles and reading People's Daily editorials. We sang songs of Mao's quotations, or gathered to dance "loyalty dance", gyrating and waving our Little Red Books. Making "loyalty dances" compulsory was one of the major orders is- sued by the Revolutionary Committees throughout China. ${ }^{(58)}$}

Although sports competition was halted during the early stage of the Cultural Revolution, sports performance and mass sport competition became part of celebration activities among the Revolutionary Communities after the $9^{\text {th }}$ Party Congress of 1969. Athletes had to dance the "loyalty dances" before competitions and recited Mao's quotations loudly when players violated a sports rule. ${ }^{(59)}$ At the same time, martial arts competitions were replaced by the development and promotion of "loyalty boxing." ${ }^{(60)}$ Many martial arts experts were denounced as ministers and sons of the

48. People's Daily, 5 August 1966, p. 1.

49. Tan Fang and Zhao Wumian, Highlights of Da-zi-bao: During the Cultural Revolution, New York, Mirror, 1996, pp. 403-404.

50. Thomas W. Robinson, The Cultural Revolution in China, Berkeley, University of California, 1971, pp. 307-312

51. See Tan Fang and Zhao Wumian, op. cit., pp. 332-335

52. Ibid.

53. Gu Shiquan's Chinese History of Sports, op. cit., Beijing, Beijing University of Physical Education, pp. 360-361.

54. Jung Chang, Wild Swans: Three Daughters of China, London, Flamingo, 1993, p. 496.

55. Yan Jiaqi and Gao Gao, Ten Years History of "The Cultural Revolution", Hong Kong, San Ming Books Press, 1989, pp. 411-412.

56. Wu Shaozu's Sports History of the People's Republic of China 1949-1999, Beijing, China Books Publisher, 1999, p. 175

57. See Yan Jiaqi and Gao Gao, op. cit., p. 494.

58. Ibid., p. 386 .

59. Ibid., pp. 502-503.

60. See Wu Shaozu's Sports History of the People's Republic of China 1949-1999, op. cit. p. 188. 
feudal era, "monsters," and reactionaries, and many valuable classical boxing books were destroyed and as the poison of feudalism, capitalism, and revisionism. Martial arts competitions were attacked as a medium of feudalism and superstition, and martial arts weapons and equipment were confiscated. ${ }^{(6)}$ This was the second setback for martial arts after 1949.

The intensity and violence of the Red Guard movement brought China to the brink of civil war from 1966 to 1969. At the same time, Mao swept away "capitalist roaders" and "covert enemies" such as President Liu Shaoqi, Party General Secretary Deng Xiaoping, Sports Minister He Long, and their followers who disregarded Mao's policies after the Great Leap Forward. ${ }^{(62)}$ Mao gradually increased the political status of the PLA and reconstructed the Party to re-establish its control over society by reorganising most of the previous state and mass organisations after the Ninth Congress of April 1969, while Premier Zhou Enlai worked to restore scientific and educational standards, including sports. Premier Zhou acknowledged China's sports achievements from 1949 to 1966 during the Cultural Revolution's first national physical culture and sports conference in July 1971, and his support inspired many sports officials and experts. Subsequently, Zhou gradually restored the sports training, competition, schools, organisations, and administration that had been discontinued between 1966 and 1970. Sports officials were reappointed to the State Physical Culture and Sports Commission, which had been dominated by the PLA between 1966 and 1971. National countryside sports development meetings, national labour sports development meetings and the national spare time physical education and sports schools conference were held in 1972. ${ }^{(63)}$

Mass sports development became an important policy of the Chinese government in 1972. For example, a traditional round-the-city race was held in the Beijing Chongwen District during the Spring Festival of 1972. The Beijing No. 26 Middle School fielded more than 100 boys and girls in 20 teams to take part in a middle school cross-country race, as described in an article entitled "Mass Physical Training." (64) The first National Middle School Sports meet was held in 1973. ${ }^{(65)}$ Sports development was interrupted again, however, when Zhou's restoration work was attacked in another political campaign. On 18 January 1974, with Mao's approval, the Party circulated a document prepared under the direction of Jiang Qing (Mao's wife) entitled "The Doctrines of Lin Biao, Confucius, and Mencius," which marked the formal start of the official campaign to "Criticize Lin Biao, criticize Confucius" (pi Lin, pi Kong). Masterminded and led by the Gang of Four (Jiang Qing, Wang Hongwen,
Zhang Chunqiao and Yao Wenyuan), and foreshadowed by the 1974 New Year's Day joint editorial in the People's Daily, Hongqi (Red Flag), and the Liberation Army News, ${ }^{(66)}$ this campaign was intended to undermine Zhou Enlai. ${ }^{(6)}$

During the restoration period, Zhou appointed Wang Meng head of the State Physical Culture and Sports Commission and permitted Physical Culture Daily to resume publication in 1971. Nonetheless, during the "Criticize Lin Biao, criticize Confucius" campaign Wang Meng was replaced by Zhuang Zedong, three-time winner of the World Table Tennis Championship, who became a confidant of Jiang Qing and organised his own clique to support the "Gang of Four." (68) Under the slogans of "sports revolution" and "sports competition reform," the Gang of Four attacked the former leaders of the State Physical Culture and Sports Commission as "third generation revisionists" and "bourgeois sports without capitalists," and gradually took over the commission and sports organisations from 1974 to 1976. Zhou Enlai made concessions to the Gang of Four regarding the State Physical Culture and Sports Commission and the Ministry of Culture, but he maintained power over the Ministry of Education during the 1974 power struggle. ${ }^{(69)}$ Chinese sports did not emerge from chaos until Mao's death on 9 September 1976 and the arrest of the "Gang of Four"

61. Yu Yun-tai, The History of the Chinese Martial Arts, Beijing, People's Sports Publishing House, 1985, p. 195.

62. Ibid., 195 and The History of the Chinese Martial Arts (1996), edited by National Research Institute of Martial Arts, Beijing, People's Sport Publishing House Press, pp. 368-369.

63. See Marc Blecher, China Against the Tides, London, Pinter, 1997, pp. 75-77.

64. See Gu Shiquan, op. cit., pp. 361-362.

65. "Upon our arrival at 6:30 in the morning, we saw some 500 students training on the sports grounds - some practicing throwing the javelin, discus, hand-grenade and other objects, some running or practicing the high jump and long jump, and some playing ball games. At 7:30, the students gathered on the large field or in the courtyards, doing setting-up exercise to music broadcast over the radio. Classes began at 8:00... and after 4:00 o'clock in the afternoon, the students played ball games and engaged in various other activities. So keen are the youngsters for ball games that they throng the sports grounds even on Sundays... Through the Great Cultural Revolution, the teacher began by way of introduction, we have come to understand that in physical training there is also the question of "For whom?" Since the purpose is to build up the people's health, we should stress the mass character of such training. It is wrong to train just a few "stars"; our duty is to help the majority of students take an interest in physical training and actively participate in sports activities... First of all, we do our best to popularize those sports which give a comparatively large amount of exercise but require no particular skill, such as running, tug of war, skipping and throwing the hand grenade... Secondly, we pay proper attention to combining athletic meets with everyday sports activities." Beijing Review, No. 14, 7 April 1972, pp. 11-13.

66. See Gu Shiquan, op. cit., p. 362.

67. See Yan Jiaqi and Gao Gao, op. cit., p. 671.

68. Roderick MacFarquhar, The Politics of China 1949-1989, Cambridge, Cambridge University, 1993, pp. 286-287.

69. See Yan Jiaqi and Gao Gao, op. cit., p. 678. 
In the 1980s, Chinese sport needs to "break out of Asia and advance into the world." (๑) IISH Collection of Stefan R. Landsberger http://www.iisg.nl/ /andsberger/

Mao ideology. Contrary to the Cultural Revolution era, competition was considered good under market economic reform. ${ }^{(77)}$ The CCP leadership encouraged the development of sport and international participation and aspirations to achieve the highest level of sports performance. ${ }^{(78)}$

Mao himself never promoted high-performance sport, but after his death the primacy of ideology in sports was gradually replaced by more Western concepts of athletics, and the Maoist emphasis on hygiene and self-discipline declined. ${ }^{(79)}$ For example, while Mao refused to anthropomorphize the contest between nation-states in sporting events, Deng Xiaoping emphasized "Promoting Sport for the Nation's Pride" in Tiyu Bao on 15 September 1983.

China began to pay serious attention to Olympic sports after the 1984 Los Angeles Olympic Games, in which China represented the largest communist presence (most communist states followed the Soviet-led boycott). China placed fourth in the 1984 Summer Olympics, a position it held again in the 1992 Barcelona Olympics. China also sent a delegation headed by Wei Zhenlan to learn from the Los Angeles Organizing Committee about how to profit from major sporting events such as the Olympic Games. China noted that sport could be profitable, and could also inspire Chinese nationalism. In particular, the success of Chinese teams at the 1984 Los Angeles Olympic Games aroused patriotism and nationalism. It was one of the first visible steps for Chinese sport to "break out of Asia and advance into the world."

The Chinese government approved two key documents in 1984 and 1986 with regard to the reform of sport. The first document was a CCP central committee dispatch, "A notification about moving further ahead in sports development," sent to all sports officials on 5 October 1984. The dispatch affirmed a number of crucial points. First, Chinese sports had developed well in the 1980s, with the great achievement of Chinese athletes at the 1984 Los Angeles Olympics proving that Chinese sports were approaching world levels of performance and had the potential to further promote Chinese national pride and self-confidence, as well as patriotism and support outside of China. Second, while Chinese sport may have progressed, there was still a gap at the very top level of international sport. To reduce this gap China envisaged promoting a truly popular sports policy that involved: (i) actively developing both rural and urban physical activities; (ii) working hard to promote people's health; (iii) training young children in school; (iv) improving training and competition systems and developing scientific training research; and (v) focusing on developing excellence in sporting events. ${ }^{\left({ }^{(0)}\right.}$

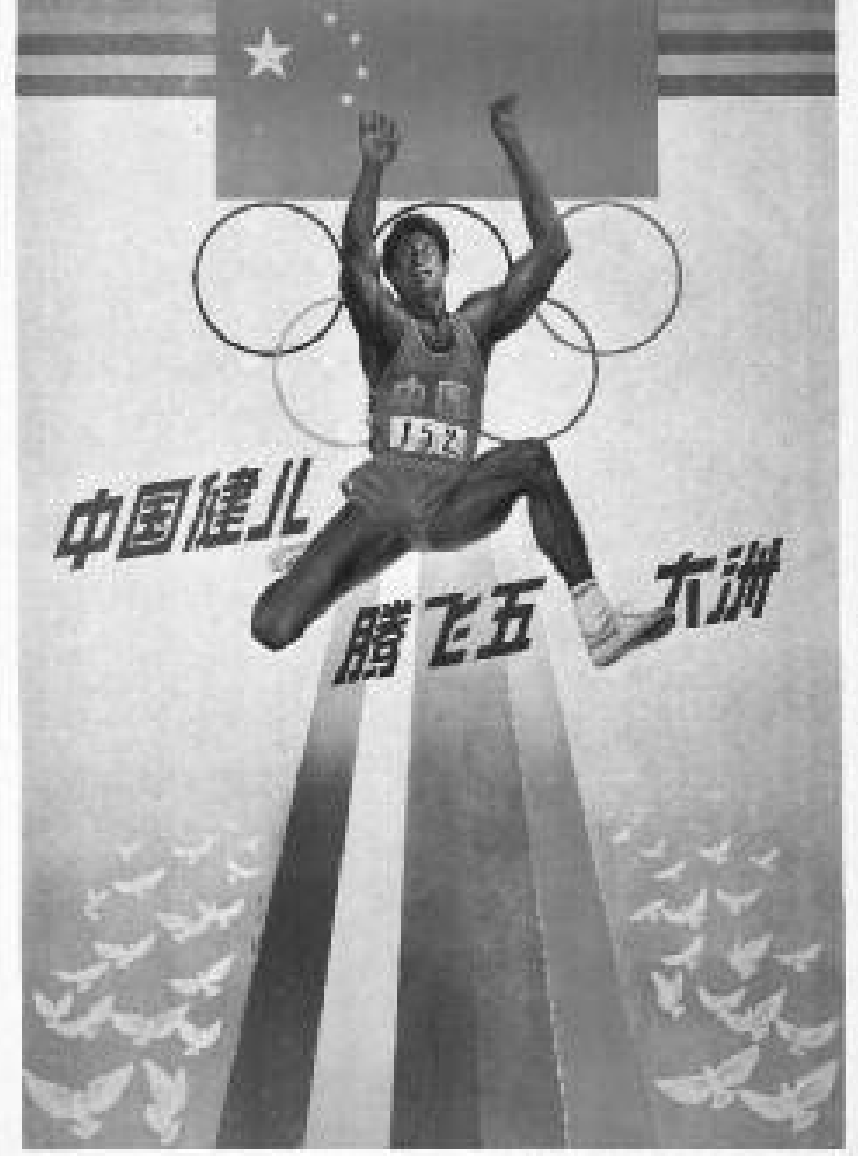

The document indicated that the state should establish a sports team both "red and expert" with excellent athletes and a coaching team. The state was to encourage excellence by rewarding athletes with honours and financial inducements, in particular for special achievement. Retired international athletes were to be encouraged to take jobs as instructors in higher education. It was suggested that the budget for sport should be increased. Furthermore, the CCP needed to strengthen sports propaganda by promoting the positive function of sport, thus popularising sports knowledge and attracting people to join in physical activities. This literature was also expected to promote patriotic education, collectivism, socialism, and communism through sports achievement. Finally, all levels of Chinese Communist Party Committees should demonstrate a concern with providing support and leadership in sport. ${ }^{(8)}$ The political functions of sports were highlighted in terms of building socialist thinking and a cultured civilization. Athletes, coaches, referees, and sports workers were to be educated as socialists with ideals, high moral standards, cultural knowledge, and discipline, all of which were to be associated with patriotism, collectivism, socialism, and communism.

However, there were still problems with some of the reforms. The State Physical Culture and Sports Commission

77. Chen Rong, "The Characteristics of the Development of Sports Ideology in New China," in The Journal of Sport History and Culture, Number 1, 23 January 1999, pp. 4-8, argues how political ideology influenced the development of sport in China after 1949.

78. Ibid., p. 303.

79. State Physical Culture and Sports Commission Policy Research Centre, "Contents of 1978 National Sport Work Conference" in Sports Documents Selections 1949-1981, Beijing, People's Sport Publishing House Press, 1982, pp. 122-131.

80. Hoberman, John, Sport and Political Ideology, London, Heinemann, 1984, p. 227.

81. Tiyu Bao, 10 November 1984: 1; Xinhua Yuebao, November 1984, pp. 104-105. 
noted that: (i) Chinese levels of achievement in sport were still below those of other advanced countries; (ii) although sports development was still influenced by leftist thought, there were weaknesses in terms of sport leadership, training, and systems of competition; (iii) sports reform was not keeping pace with economic reform; and (iv) the sports system needed greater uniformity. The Commission published a further document in 1986 outlining a draft proposal for reforming the sports system, which was passed on 15 April 1986. This draft policy contained clauses relating to: (i) improving the level of sport leadership and confirming the State Physical Culture and Sports Commission's overall role of leadership, coordination, and supervision; (ii) establishing a scientific training system; (iii) improving the system of sport competitions; (iv) enhancing and promoting Chinese traditional indigenous sports; (v) developing sports scientific research gradually; (vi) reforming the sport and physical education system; (vii) enhancing political thought on sport; (viii) improving the sport prize system; and (ix) developing flexible open polices in relation to international sport. ${ }^{(82)}$

All in all, the period between 1978 and 1989 marked a distinctive stage in the development of sport in China. It was a stage during which China questioned most of the basic elements of Maoism and sought a new form of political authority, economic activity, social organization, and cultural expression. Sport in some ways reflected the challenge of moving steadily into the global sports system on China's terms, while at the same time wrestling with external expectations of sporting ideals and democracy. Society's state and class structures were undergoing a basic transformation under the CCP's reform policies, and sports were incorporated into this reform. During the first decade of Deng's reforms, the impulses for political and economic structural reform tended to ebb and flow. As the 1989 democracy movement drew the decade to a close, it became clear that economic change had advanced faster than political change, but sports reforms still enjoyed the full support of the government. The 1990 Asian Games in Beijing were a major political and social event for China, and signalled to the rest of the world that China was in the market for hosting major international sporting events. Through its control over television and print news coverage, the government sought to use the Games to boost morale and confidence in the wake of the disaster of 1989. China did well in terms of medals, far better than other countries, and the Chinese people were enthusiastic about the Games, in particular the opening and closing ceremonies. Even people who expressed anti-government views seemed to be proud of the Games. Thus, the government used the Asian
Games to convince the world of China's intention to continue and even expand its policies of reform. As Jiang Zemin claimed, while moving at its own pace, China would quickly be seen to "set up the process of reform and opening up to the outside world." (83)

\section{One century, one ideology}

Through a historical sociological analysis of sport, Maoism, and the Beijing Olympics, we perceive Western imperialism as the agent bringing modern sports into China. Since the establishment of Republican China in 1911, Chinese people had lived under the constant threat of civil war and imperialism, so it is not surprising that national defence was a primary consideration of sports, and that sports were often associated with nationalism in China.

Mao's thoughts on physical culture and sport were fostered within this military and nationalist atmosphere. Mao expressed his anti-intellectualist ${ }^{(84)}$ attitude and admiration for bestiality (shouxing zhuyi) in his later thoughts on physical culture and the physical training programs of the Red Army. In Mao's Socialist New China, the first step was to import the socialist sports system from Soviet Union in the 1950s. Later, as Mao decided to experiment with a uniquely Chinese form of utopia, with tragic consequences, the development of sport was interrupted, and sports officials suffered both mentally and physically during the Cultural Revolution from 1966 to 1976.

Maoist sports embodied a specific ideology, combining Chinese nationalism and the ideology of Communist revolution. Unlike other Soviet or post-colonial Third World countries, China under Mao was prevented from using competitive sports as nationalist tools to defeat capitalist or imperialist counties by its isolation in the international arena. The ideology of "friendship first, competition second," for example, reflected the radical "ultra-left" and "self-reliance" policy behind Mao's hostility to both the U.S. and the Comintern (including the Soviet Union).

Some writers have argued that China began to concentrate its resources on elite athletes in order to produce high performances in the international arena in the period of Great Leap Forward, ${ }^{\left({ }^{(5)}\right)}$ and that this represented a turning point

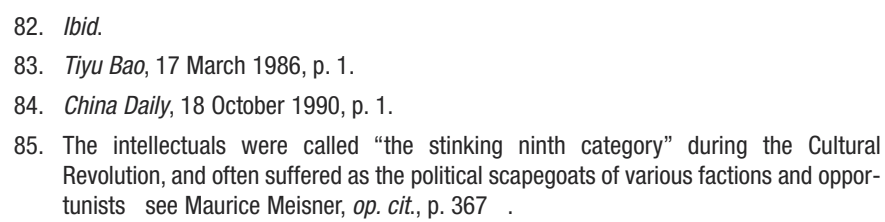

85. The intellectuals were called "the stinking ninth category" during the Cultura Revolution, and often suffered as the political scapegoats of various factions and opportunists see Maurice Meisner, op. cit., p. 367 
from mass to elite sport in China. Fan concludes that the Cultural Revolution movement was "not all bad" because it contributed to making sport a powerful ideological vehicle for achieving diplomatic policies. ${ }^{(86)}$ The Cultural Revolution also increased the exposure of rural peasants and women to modern sports. Since Mao's death in 1976, China has experienced a cultural and ideological transformation unprecedented in the history of communist societies. In particular, sport has become one of the most important cultural phenomena in China as Maoist socialism has gradually subsided. Sport in China has been widely promoted with the spread of capitalism and its consumer culture in the last two decades. At the same time, however, there are indications that Maoist nationalist ideology has been retained in the post-Mao era. For example, after NATO's accidental bombing of the Chinese Embassy in Belgrade on 8 May 1999, the Chinese government temporarily banned television broadcasts of NBA basketball games in protest. ${ }^{\left({ }^{(87)}\right.}$

On the other hand, an increasing number of Western and Chinese researchers over the last two decades have been examining sport in China through a post-colonial theoretical framework. ${ }^{(88)} \mathrm{A}$ number of postcolonial writers use criticism of Western universalism as a basis for explaining non-Western problems. ${ }^{\left({ }^{(8)}\right)}$ Dualism or essentialism should be avoided when exploring sport culture in China. Indeed, it seems that some writings use "Chineseness" in the same way that "sick man" has been used to understand a world construed as manifestly different. ${ }^{(90)}$ In Chinese works, the connection of sport with the notion of "sick man" is even more apparent and popular, as in From Sick Man of Asia to Sports Superpower:

It was the Western powers that opened the door of China... evil smuggling of opium into China... ruined the physique of the Chinese people... imposed upon them the shameful name of 'Sick Man of Asia."'(9)

In conclusion, this paper has examined both Chinese and Western works to illustrate how scholars and writers may use Orientalist notions as a vehicle to extol or criticize the development of sport in China. Specifically, these works have not only represents the Chinese as "imagined Olympians," but have also re-invented the "sick man" stereotype that was essential to the development of Maoist thought. It is important to recognize that the notion of post-colonialism has brought a new perspective to analyse the problematic kernel of nationalist ideology at the heart of the hybrid formed by sport, Maoism, and the Beijing Olympics.

86. Fan Hong, "Not all Bad: Communism, Society and Sport in the Great Proletarian Revolution: A Revisionist Perspective," International Journal of the History of Sport, Vol. 16 (3), 1999, pp.47-71

87. Ibid.

88. Dong-Jhy Hwang and Grant Jarvie, "Sport, Postcolonialism and Modern China: Some Preliminary Thoughts," in John Bale and Mike Cronin (eds), Sport and Postcolonialism, Oxford, Berg, 2003, pp. 73-90.

89. For example, Susan Brownell, Training the Body for China: Sport in the Moral order of the People's Republic, op. cit; Fan Hong, Footbinding, Feminism and Freedom: the Liberation of Women's Bodies in Modern China, London, Frank Cass, 1996; Grant Jarvie et al., Sport, Revolution and the Beijing Olympics, Oxford, Berg, 2008; Howard G. Knuttgen, et al., Sport in China, Illinois, Human Kinetics Books, 1990; and James Riordan and Robin Jones (eds), Sport and Physical Education in China, London, E \& FN Spon, 1999.

90. Some postcolonial writers include: Homi K. Bhabha, The Location of Culture, London, Routledge, 1994; E.W. Said, Culture and Imperialism, London, Vintage, 1993, and Orientalism, London, Penguin Books, 1995; G.C. Spivak, In Other Words: Essays in Cultural Politics, London, Routledge, 1987, and The Post-Colonial critic: Interviews, Strategies, Dialogues, London, Routledge, 1990; and A.R. Jan Mohamed, "The Economy of Manichean Allegory: The Function of Racial difference," Critical Inquiry, 12, 1985, pp.59-87.

91. Said, Orientalism, op. cit., p. 12.

92. Gao Cui, op. cit., p. 9. 